\title{
Optimasi Diversifikasi Usaha Ternak Domba Tanaman Kopi dan Tanaman Pangan, Studi Kasus di Lembaga Masyarakat Desa Hutan (LMDH) Taman Putri Desa Kemiri Kecamatan Panti, Kabupaten Jember Indonesia
}

\section{(Optimization the Diversification of Lamb Breeding, Coffee Planting and Food Crops, Case Study of the Forest Rural Community Organization (LMDH) of Taman Putri in Kemiri Village, Panti District Jember Regency - Indonesia)}

\author{
Setyawan $\mathrm{HB}^{1}$, Utami $\mathrm{DH}^{2}$ \\ ${ }^{1}$ Program Studi Peternakan Fakultas Pertanian Universitas Jember \\ ${ }^{2}$ Fakultas Peternakan Universitas Brawijaya Malang, Jl. Veteran, Malang, Indonesia \\ hidayat.bs.faperta@unej.ac.id
}

\begin{abstract}
The objectives of the research was to optimize the diversification of lamb breeding, coffee planting and food crops in Kemiri Village, Panti Subdistrict, Jember District conducted in July to September 2016. The approach used in the diversification optimization of crop farming - lamb breeding is Linear Programming analysis. Observations were made using survey methods of 119 households of coffee farmers (29 farm households with food crops on farms or Model 1 and 90 farm households without food crops or Model 2). Respondents were chosen based on the cluster method with the condition that the respondent were members of The Forest Rural Community Organization (LMDH) Taman Putri and has lamb breeding. The results showed that Model 1 and Model 2 during this work is not optimal. Optimal condition of farmers Model 1: average of lamb breeding 1,59 ST, with average contribution 1,35\%. Model 2: average of lamb breeding 1,49 ST, with rate contribution 71,75\%.
\end{abstract}

Key words: Farming optimization, coffee crop, lamb breeding, linear programming

\begin{abstract}
ABSTRAK
Tujuan penelitian adalah mengoptimalkan diversifikasi usaha kebun (tanaman kopi dan pelindung), tanaman pangan (padi) dengan ternak domba di desa Kemiri, Kecamatan Panti, Kabupaten Jember. Pendekatan yang digunakan adalah analisis Linear Programming,dan pengamatan dilakukan dengan metode survei terhadap 119 rumah tangga petani kopi rakyat (29 rumah tangga petani yang memiliki usahatani tanaman pangan di lahan pertanian atau Model 1 dan 90 rumah tangga petani yang tidak memiliki usahatani tanaman pangan atau Model 2). Responden dipilih berdasar metode kluster dengan syarat responden adalah petani anggota Lembaga Masyarakat Desa Hutan (LMDH) Taman Putri dan memiliki domba. Hasil penelitian menunjukkan bahwa Model 1 dan Model 2 selama ini bekerja tidak optimal dan kondisi optimal petani LMDH Model 1: rerata ternak domba 1,59 ST, dengan rerata kontribusi 1,35\%. Petani LMDH Model 2: rerata ternak domba 1,49 ST, dengan rerata kontribusi $71,75 \%$.
\end{abstract}

Kata kunci: Optimasi usahatani, tanaman kopi, ternak domba, linier programming 


\section{PENDAHULUAN}

Diversifikasi pertanian diartikan sebagai usaha yang dilakukan petani untuk meningkatakan produksi dengan cara melakukan penganekaragaman usahatani atau komoditas, misalnya pertanian campuran (mix farming), tumpangsari, mina padi tanpa meninggalkan tanaman pokok (Effendi 1995). Usahatani terpadu merupakan suatu konsep yang memandang usahatani sebagai suatu sistem dan umumnya dilakukan oleh kebanyakan petani di Indonesia. Pada awalnya petani melakukan diversifikasi usahatani dengan alasan untuk memenuhi konsumsi keluarga, kemudian berkembang untuk memenuhi permintaan pasar dan meningkatkan pendapatan (Rusastra et al. 2004).

Usahatani yang dilakukan secara terpadu atau diversifikasi mengarah kepada usaha yang terintegrasi sehingga antara usaha satu dengan lainnya saling memberikan manfaat. Menurut Rusastra et al. 2004, pengembangan diversifikasi perlu dilakukan secara rasional dan dinamis dengan mempertimbangkan perubahan faktor lingkungan dan permintaan pasar agar memberikan manfaat maksimal dalam peningkatan produksi dan pendapatan petani.

Diversifikasi merupakan pilihan kebijakan untuk meningkatkan pertumbuhan perekonomian desa. Usahatani terpadu dengan beberapa komoditas tanaman pangan, ikan dan ternak ruminansia kecil memberikan pendapatan tertinggi dibanding dengan usahatani hanya dua komoditas tanaman pangan dan ikan (Hidayat 2007).

Pengembangan usaha ternak ruminansia kecil (kambing/domba) perlu memperhatikan tiga komponen utama yang saling terkait, yaitu tersedianya lahan, ternak, dan pakan (Soedarjat 2000). Konsep pertanian integrasi tanaman - ternak telah diterapkan di Indonesia sejak lama sebagaimana terjadi di negara-negara Asia Tenggara (Diwyanto et al. 2004). Sebagaimana pada umumnya petani kecil, sistem pertanian masih dikelola secara tradisional, namun dapat diperbaiki menjadi lebih optimal (Dent et al. 1971).

Hasil penelitian Sudaryanti (2004) menyatakan bahwa faktor-faktor yang signifikan mempengaruhi produksi kopi rakyat di Kabupaten Temanggung adalah luas lahan, jumlah tanaman, dan penggunaan pupuk. Tenaga kerja pengaruhnya tidak signifikan, berarti pemakaian tenaga kerja pada usaha perkebunan kopi rakyat terlalu banyak dibandingkan dengan hasil produksinya. Produksi kopi di wilayah penelitian tersebut berada pada kondisi return to scale cenderung menurun, tetapi relatif kecil. Hal tersebut disebabkan karena input produksinya belum diaplikasikan secara optimal sehingga menimbulkan kondisi yang kontra produktif.

Penelitian Diwyanto et al. (2004) menyimpulkan bahwa model pengembangan wilayah diarahkan pada Crop Livestock System (CLS) yaitu keterpaduan usahatani (farming system) antara perkebunan dengan peternakan atau perikanan (sistem tanamanternak). Keuntungan penerapan CLS juga dinyatakan Devendra (1999), yaitu (1) diversifikasi penggunaan sumberdaya produksi, (2) mengurangi terjadinya resiko, (3) efisiensi penggunaan tenaga kerja, (4) efisiensi penggunaan komponen produksi, (5) mengurangi ketergantungan energi kimia dan energi biologi serta masukan sumberdaya lainnya dari luar, (6) sistem ekologi lebih lestari dan tidak menimbulkan polusi sehingga melindungi lingkungan hidup, (7) meningkatkan output, dan (8) mengembangkan rumah tangga petani yang lebih stabil.

Shamim et al. (2011) menyatakan bahwa petani di Bangladesh pada umumnya telah mempraktekkan sistem pertanian terpadu (IFS), sehingga ketidakpastian pendapatan dapat teratasi. Sistem IFS dapat memecahkan masalah ekonomi dan ekologi, menyediakan kebutuhan rumah tangga lainnya seperti bahan bakar, pupuk dan pakan dan juga dapat meningkatkan produktivitas tanaman. Ezeaku et al. (2015) menyatakan bahwa 
sistem peternakan tanaman terpadu telah sering dianjurkan sebagai salah satu solusi yang paling menjanjikan untuk mengatasi penurunan kesuburan tanah dan kehilangan produktivitas dalam sistem pertanian di Nigeria. Meningkatnya produktivitas ternak dalam hal penambahan berat badan, produksi susu dan akan membuat tidak hanya menguntungkan tetapi juga memasok kebutuhan protein pada masyarakat perkotaan.

Menurut Sugandi (2007), usatani ternak domba mampu menunjang usahatani padi melalui kotoran ternak yang dihasilkan sehingga mengurangi penggunaan pupuk kimia serta berperan dalam mengatasi kebutuhan biaya yang mendesak karena dapat ditukarkan uang dalam waktu cepat.

Peluang usahatani tanaman - ternak domba secara terpadu di Desa Kemiri Kecamatan Panti Kabupaten Jember cukup besar, mengingat daerah tersebut memiliki potensi ternak domba terbesar di wilayah Provinsi Jawa Timur. Juga di Kabupaten Jember memiliki Unit Pelaksana Teknis Pembibitan Ternak dan Hijauan Makanan Ternak (UPTPT dan HMT).

Perhutani memberikan hak kelola lahan hutan kepada Lembaga Masyarakat Desa Hutan (LMDH) dengan tujuan agar masyarakat ikut melestarikan hutan dan melakukan budidaya tanaman kopi. Tujuan penelitian adalah menentukan kondisi optimal usaha kebun (tanaman kopi, dan tanaman pelindung serta tanaman pangan) dengan usaha ternak domba pada petani kopi rakyat LMDH Taman Putri, dengan memperhatikan aspek ekonomi dan lingkungan. Tujuan ekonomi: (a) memaksimumkan pendapatan lahan perkebunan; (b) memaksimumkan pendapatan usaha ternak domba; dan (c) memaksimumkan pendapatan tanaman pangan. Tujuan lingkungan: (a) memaksimumkan perolehan pakan ternak dari tanaman pelindung; dan (b) memaksimumkan perolehan kotoran ternak domba untuk pupuk. Secara riil, petani LMDH juga menanam tanaman holtikultura (alpukat, durian, nangka, pisang, sengon dan petai) namun dalam jumlah kecil, sehingga dalam penelitian ini diabaikan. Hasil penelitian diharapkan menjadi acuan pelaksanaan pengembangan tanaman kopi dan usaha ternak domba di lahan Perhutani yang serupa untuk meningkatkan kesejahteraan petani sesuai dengan kondisi lingkungan spesifik lokasi.

\section{METODE PENELITIAN}

\section{Rancangan penelitian}

Lokasi penelitian: Desa Kemiri, Kecamatan Panti, Kabupaten Jember, mengingat di lokasi ini ada kelompok petani kopi rakyat yang tergabung dalam LMDH Taman Putri dan telah melaksanakan diversifikasi usahatani dengan ternak domba. Populasi petani LMDH sebanyak 119 rumah tangga dengan rincian: 29 rumah tangga petani yang memiliki usahatani tanaman pangan (Model 1) dan memiliki ternak domba; dan 90 rumah tangga petani LMDH (Model 2) yang hanya mengelola tanaman kopi dan ternak domba; yang masing-masing terkelompokkan dalam strata berdasar modus luas kepemilikan dan penguasaan lahan. Pada Model 1: Strata $1(<0,22 \mathrm{Ha})$, Strata $2(\geq 0,22-0,53 \mathrm{Ha})$ dan Strata $3(>0,53 \mathrm{Ha})$; sedang pada Model 2: Strata $1(<0,20 \mathrm{Ha})$, Strata $2(\geq 0,20-0,50$ $\mathrm{Ha})$, dan Strata 3 (> 0,50 Ha). 


\section{Metode analisis data}

\section{Linear programming}

Analisis data yang digunakan dalam penelitian adalah analisis Program Linier atau linear programming (LP) (Lee 2002; Ijiri 2005). Analisis LP kedua kelompok petani LMDH (Model 1 dan Model 2) dilakukan terpisah.

Salah satu pendekatan dalam optimasi adalah Linear Programming (LP). Ide dasar LP adalah melibatkan tujuan manajerial (managerial objectives) khusus ke dalam formulasi LP. Secara matematis dapat dituliskan sebagai berikut (Hillier et al. 2009).

$\mathrm{Z}_{\max / \min }=\Sigma \mathrm{c}_{\mathrm{j} 1} \mathrm{X}_{\mathrm{j}}$

$\mathrm{j}=1$.

$\mathrm{X}_{1}, \mathrm{X}_{2}, \ldots, \mathrm{X}_{\mathrm{n}}=$ variabel keputusan,

$c_{j k}=$ koefisien $X_{j}(j=1,2, \ldots, n)$ fungsi obyektif tujuan-k $(k=1,2, \ldots, k)$,

$\mathrm{g}_{\mathrm{k}}=$ kapasitas sumberdaya-k.

Dengan mempertimbangkan kendala-kendala :

(2.3)

${ }^{\mathrm{n}} \mathrm{c}_{\mathrm{j} 1} \mathrm{X}_{\mathrm{j}} \leq ; \geq ;=\mathrm{g}_{1}$

$\mathrm{j}=1$.

Fungsi tujuan dalam formulasi model ada tiga, yaitu sebagai berikut:

a. Tujuan 1 : memaksimumkan pendapatan bersih usaha kebun.

$\mathrm{Z}_{\max }=0,021 \mathrm{X}_{1}+0,0002 \mathrm{X}_{2}$

b. Tujuan 2 : memaksimumkan pendapatan bersih usaha ternak.

$$
\mathrm{Z}_{\max }=1,14 \mathrm{X}_{3}
$$

c. Tujuan 3 : memaksimumkan pendapatan bersih usahatani tanaman pangan.

$$
\mathrm{Z}_{\max }=0,50 \mathrm{X}_{4}
$$

Keterangan :

$\mathrm{X}_{1}=$ tanaman kopi (ha/tahun); $\mathrm{X}_{2}=$ tanaman pelindung (ha/tahun)

$\mathrm{X}_{3}=$ ternak domba $(\mathrm{ST} / \mathrm{tahun}) ; \mathrm{X}_{4}=$ tanaman pangan (ha/tahun)

\section{Kendala-kendala}

Variabe kendala $\rightarrow$ Keterangan

(C1) $1,14 \mathrm{X}_{3} \geq 10.000 \rightarrow$ kendala keuntungan dari ternak domba (Rp 000/tahun)

(C2) $0,15 \mathrm{X}_{3} \geq 0,57 \rightarrow$ kendala pertumbuhan populasi ternak (ST/tahun)

(C3) $\mathrm{X}_{3} \leq 2,14 \rightarrow$ kendala jumlah pemeliharaan ternak domba (ST/tahun)

(C4) $0,02 \mathrm{X}_{2} \geq 1.500 \rightarrow$ kendala perolehan pakan ternak dari tanaman pelindung ( $\mathrm{kg} /$ tahun)

(C5) $0,5 \mathrm{X}_{4} \geq 12.000 \rightarrow$ kendala pendapatan bersih dari tanaman pangan ( $\mathrm{Rp} 000 /$ tahun)

(C6) $1,75 \mathrm{X}_{3} \geq 2.500 \rightarrow$ kendala kotoran ternak ( $\mathrm{kg} /$ tahun) 
(C7) $0,04 \mathrm{X}_{1}=2 \rightarrow$ kendala jarak tanam pohon kopi (meter)

(C8) $\mathrm{X}_{1} \leq 0,200 \rightarrow$ kendala luas lahan yang bisa ditanami kopi (ha/tahun)

(C9) $\mathrm{X}_{1}-\mathrm{X}_{2} \geq 0 \rightarrow$ kendala perimbangan tanaman pelindung dan tanaman kopi (ha/tahun).

(C10) $\mathrm{X}_{4} \leq 0,02 \rightarrow$ kendala luas lahan pertanian yang bisa untuk tanaman pangan (ha/tahun)

Formulasi pada kelompok petani Model 2 yang hanya berusahatani tanaman kopi mirip formulasi Model 1, dengan tujuan 3 diabaikan. Aplikasi Add-in Excel (Solver) digunakan untuk memperoleh solusi optimal. Modal usaha untuk tanaman kopi dan usaha ternak domba mudah diakses dari lembaga keuangan milik pemerintah (BRI, Bank Mandiri, BNI 1946) dan milik swasta (Bukopin, Danamon, BCA, Sinar Mas).

Demikian pula, tenaga kerja yang umumnya anggota keluarga dan tetangga merupakan sumberdaya yang cukup melimpah (Sudaryanti 2004; Devendra 1999).

\section{HASIL DAN PEMBAHASAN}

\section{Usahatani diversifikasi tanaman kopi - ternak domba riil}

Pendapatan bersih dan kontribusi masing-masing komponen diversifikasi usahatani riil dalam satu tahun terakhir kelompok petani LMDH Model 1 adalah:

Tabel 1. Pendapatan bersih riil/tahun pada model $1(\mathrm{Rp} 000.000)$

\begin{tabular}{lcccccc}
\hline \hline \multirow{2}{*}{$\begin{array}{l}\text { Komponen } \\
\text { diversifikasi }\end{array}$} & Volume & $\begin{array}{c}\text { Pendapatan } \\
\text { bersih }\end{array}$ & Volume & $\begin{array}{c}\text { Pendapatan } \\
\text { bersih }\end{array}$ & Volume & $\begin{array}{c}\text { Pendapatan } \\
\text { bersih }\end{array}$ \\
\cline { 2 - 7 } & \multicolumn{2}{c}{ Strata 1} & \multicolumn{2}{c}{ Strata 2} & Strata 3 \\
\hline $\begin{array}{l}\text { Tanaman } \\
\text { kopi }\end{array}$ & $0,20 \mathrm{ha}$ & 2,317 & $0,50 \mathrm{ha}$ & 7,158 & $1,0 \mathrm{ha}$ & 18,230 \\
$\begin{array}{l}\text { Kulit kopi } \\
\text { Pelindung }\end{array}$ & $268,34 \mathrm{~kg}$ & 0,537 & $440 \mathrm{~kg}$ & 0,880 & $838,89 \mathrm{~kg}$ & 1,678 \\
$\begin{array}{l}\text { Ternak } \\
\text { domba }\end{array}$ & $0,20 \mathrm{ha}$ & 12,768 & $0,50 \mathrm{ha}$ & 11,664 & $1,0 \mathrm{ha}$ & $1, .840$ \\
$\begin{array}{l}\text { Kotoran } \\
\text { ternak }\end{array}$ & $6.065 \mathrm{~kg}$ & 1,213 & $4.200 \mathrm{~kg}$ & 0,840 & $5.111 \mathrm{~kg}$ & 1,022 \\
$\begin{array}{l}\text { Padi } \\
\begin{array}{l}\text { Total pendapatan } \\
\text { bersih/tahun }\end{array}\end{array}$ & $0,02 \mathrm{ha}$ & 2,318 & $0,03 \mathrm{ha}$ & $7, .182$ & $0,05 \mathrm{ha}$ & 10,253 \\
\hline
\end{tabular}

$\mathrm{ST}=1$ satuan ternak $=7$ ekor ternak (Ensminger 1991)

Semakin luas penguasaan lahan kebun kopi dan lahan pertanian, petani cenderung lebih mengutamakan budidaya kopi dan usahatani tanaman pangan, dan curahan waktu untuk usaha ternak menjadi lebih kecil.

Pendapatan bersih dan kontribusi masing-masing komponen diversifikasi usahatani riil dalam satu tahun terakhir kelompok petani LMDH Model 2 adalah: 
Tabel 2. Pendapatan bersih riil/tahun pada model 2 (Rp 000.000)

\begin{tabular}{|c|c|c|c|c|c|c|}
\hline \multirow{2}{*}{$\begin{array}{l}\text { Komponen } \\
\text { diversifikasi }\end{array}$} & Volume & $\begin{array}{l}\text { Pendapatan } \\
\text { bersih }\end{array}$ & Volume & $\begin{array}{l}\text { Pendapatan } \\
\text { bersih }\end{array}$ & Volume & $\begin{array}{c}\text { Pendapatan } \\
\text { bersih }\end{array}$ \\
\hline & \multicolumn{2}{|c|}{ Strata 1} & \multicolumn{2}{|c|}{ Strata 2} & \multicolumn{2}{|c|}{ Strata 3} \\
\hline Tanaman kopi & 0,20 ha & 2,177 & 0,50 ha & 5,495 & 1,0 ha & 10,872 \\
\hline Kulit kopi & $277,79 \mathrm{~kg}$ & 0,556 & $479,41 \mathrm{~kg}$ & 0,959 & $\begin{array}{l}814,29 \\
\mathrm{~kg}\end{array}$ & 1,629 \\
\hline Pelindung & 0,20 ha & 12,769 & 0,50 ha & 11,372 & 1,0 ha & 11,571 \\
\hline Ternak domba & $1,41 \mathrm{ST}$ & 11,255 & $1,25 \mathrm{ST}$ & 9,965 & $1,50 \mathrm{ST}$ & 11,990 \\
\hline $\begin{array}{l}\text { Kotoran } \\
\text { ternak }\end{array}$ & $\begin{array}{l}6.112,9 \\
\mathrm{~kg}\end{array}$ & 1,223 & $6.153,9 \mathrm{~kg}$ & 1,231 & $\begin{array}{l}6.386,4 \\
\mathrm{~kg}\end{array}$ & 1.228 \\
\hline $\begin{array}{l}\text { Total pendapata } \\
\text { bersih/tahun }\end{array}$ & & 27,980 & & 29,021 & & 37,289 \\
\hline
\end{tabular}

Usahatani integrasi tanaman - ternak domba optimal dengan pendekatan LP

Pendapatan bersih dan kontribusi masing-masing komponen diversifikasi usahatani optimal dalam satu tahun terakhir kelompok petani LMDH Model 1 adalah:

Tabel 3. Pendapatan bersih optimal/tahun pada model 1 (Rp 000.000)

\begin{tabular}{|c|c|c|c|c|c|c|}
\hline $\begin{array}{l}\text { Komponen } \\
\text { diversifikasi }\end{array}$ & Volume & $\begin{array}{l}\text { Pendapatan } \\
\text { bersih }\end{array}$ & Volume & $\begin{array}{l}\text { Pendapatan } \\
\text { bersih }\end{array}$ & Volume & $\begin{array}{c}\text { Pendapatan } \\
\text { bersih }\end{array}$ \\
\hline \multicolumn{7}{|c|}{ Tujuan 1: Memaksimumkan pendapatan bersih usaha kebun } \\
\hline & \multicolumn{2}{|c|}{ Strata 1} & \multicolumn{2}{|c|}{ Strata 2} & \multicolumn{2}{|c|}{ Strata 3} \\
\hline Tanaman kopi & 0,12 ha & 12,305 & 0,32 ha & 19,842 & 0,84 ha & 56,485 \\
\hline Kulit kopi & $192 \mathrm{~kg}$ & 0,576 & $512 \mathrm{~kg}$ & 1,024 & $1.344 \mathrm{~kg}$ & 2,688 \\
\hline Pelindung & 0,12 ha & 2,160 & 0,32 ha & 3,840 & 0,84 ha & 10,080 \\
\hline Ternak domba & $1,18 \mathrm{ST}$ & 7,530 & $1,65 \mathrm{ST}$ & 10,725 & $1,83 \mathrm{ST}$ & 10,953 \\
\hline Kotoran ternak & $2.880 \mathrm{~kg}$ & 0,288 & $4.320 \mathrm{~kg}$ & 0,432 & $4.320 \mathrm{~kg}$ & 0,432 \\
\hline Padi & 0,022 ha & 5,961 & 0,037 ha & 10,042 & 0,049 ha & 13,103 \\
\hline \multicolumn{2}{|c|}{ Total pendapatan bersih/th } & 28,820 & & 45,905 & & 93,741 \\
\hline
\end{tabular}

Tujuan 2: Memaksimumkan pendapatan bersih usaha ternak Strata 1

Strata 2

Strata 3

\begin{tabular}{|c|c|c|c|c|c|c|}
\hline Tanaman kopi & 0,11 ha & 6,425 & 0,35 ha & 22,362 & 0,85 ha & 57,325 \\
\hline Kulit kopi & $176 \mathrm{~kg}$ & 0,352 & $560 \mathrm{~kg}$ & 1,120 & $1.360 \mathrm{~kg}$ & 2,720 \\
\hline Pelindung & 0,11 ha & 1,320 & 0,35 ha & 4,200 & 0,85 ha & 10,200 \\
\hline Ternak domba & $1,25 \mathrm{ST}$ & 7,530 & $1,85 \mathrm{ST}$ & 12,094 & $1,98 \mathrm{ST}$ & 10,953 \\
\hline Kotoran ternak & $2.880 \mathrm{~kg}$ & 0,288 & $4.680 \mathrm{~kg}$ & 0,468 & $4.320 \mathrm{~kg}$ & 0,432 \\
\hline Padi & 0,22 ha & 5,961 & 0,037 ha & 10,042 & 0,049 ha & 13,103 \\
\hline \multicolumn{2}{|c|}{ Total pendapatan bersih/th } & 21,876 & & 50,286 & & 94,733 \\
\hline
\end{tabular}


Lanjutan Tabel 3. Pendapatan bersih optimal/tahun pada model 1 (Rp 000.000)

Tujuan 3: Memaksimumkan pendapatan bersih usahatani

\begin{tabular}{lllllll} 
& \multicolumn{2}{c}{ Strata 1 } & \multicolumn{2}{c}{ Strata 2 } & \multicolumn{2}{c}{ Strata 3 } \\
\hline Tanaman kopi & $0,11 \mathrm{ha}$ & 6,425 & $0,43 \mathrm{ha}$ & 29,082 & $0,87 \mathrm{ha}$ & 59,005 \\
Kulit kopi & $176 \mathrm{~kg}$ & 0,352 & $688 \mathrm{~kg}$ & 1,376 & $1.392 \mathrm{~kg}$ & 2,784 \\
Pelindung & $0,11 \mathrm{ha}$ & 1,320 & $0,43 \mathrm{ha}$ & 5,160 & $0,87 \mathrm{ha}$ & 10,440 \\
Ternak domba & $1,20 \mathrm{ST}$ & 7,530 & $1,85 \mathrm{ST}$ & 10,953 & $1,56 \mathrm{ST}$ & 10,953 \\
Kotoran ternak & $2.880 \mathrm{~kg}$ & 0,288 & $4.320 \mathrm{~kg}$ & 0,432 & $4.320 \mathrm{~kg}$ & 0,432 \\
Padi & $0,021 \mathrm{ha}$ & 5,661 & $0,028 \mathrm{ha}$ & 7,442 & $0,048 \mathrm{ha}$ & 12,803 \\
\multicolumn{2}{l}{ Total pendapatan bersih/th } & 21,576 & & 54,445 & & 96,417 \\
\hline
\end{tabular}

Total pendapatan bersih/tahun optimal seluruh strata pada Tujuan 1, Tujuan 2 dan Tujuan 3, memiliki hubungan positif linier terhadap luas lahan. Kontribusi kulit kopi merupakan opportunity cost untuk mengurangi biaya bahan campuran dalam pembuatan pupuk organik. Kontribusi tanaman pelindung (X2) merupakan opportunity cost untuk mengurangi biaya pakan ternak domba. Kontribusi kotoran ternak domba merupakan opportunity cost untuk mengurangi biaya bahan campuran dalam pembuatan pupuk organik.

Tabel 4. Pendapatan Bersih Optimal/Tahun pada Model 2 (Rp 000.000)

\begin{tabular}{|c|c|c|c|c|c|c|}
\hline $\begin{array}{l}\text { Komponen } \\
\text { diversifikasi }\end{array}$ & Volume & $\begin{array}{l}\text { Pendapatan } \\
\text { bersih }\end{array}$ & Volume & $\begin{array}{l}\text { Pendapatan } \\
\text { bersih }\end{array}$ & Volume & $\begin{array}{l}\text { Pendapatan } \\
\text { bersih }\end{array}$ \\
\hline
\end{tabular}

Tujuan $1:$ Memaksimumkan pendapatan bersih usaha kebun

\begin{tabular}{lllllll}
\hline & Strata 1 & \multicolumn{3}{c}{ Strata 2} \\
\hline Tanaman kopi & $0,14 \mathrm{ha}$ & 8,592 & $0,31 \mathrm{ha}$ & 18,221 & $0,89 \mathrm{ha}$ & 58,442 \\
Kulit kopi & $224 \mathrm{~kg}$ & 0,448 & $496 \mathrm{~kg}$ & 0,992 & $1.424 \mathrm{~kg}$ & 2,848 \\
Pelindung & $0,14 \mathrm{ha}$ & 1,680 & $0,31 \mathrm{ha}$ & 3,720 & $0,89 \mathrm{ha}$ & 10,680 \\
Ternak domba & $1,28 \mathrm{ST}$ & 8,999 & $1,43 \mathrm{ST}$ & 10,040 & $1,57 \mathrm{ST}$ & 10,040 \\
Kotoran ternak & $3.240 \mathrm{~kg}$ & 0,320 & $3.960 \mathrm{~kg}$ & 0,396 & $3.960 \mathrm{~kg}$ & 0,396 \\
\multicolumn{2}{l}{ Total pendapatan bersih/th } & 19,944 & & 33,369 & & 82,406
\end{tabular}

Tujuan 2: Memaksimumkan pendapatan bersih usaha ternak

\begin{tabular}{lllllll}
\hline & Strata 1 & \multicolumn{3}{c}{ Strata 2} \\
\hline Tanaman kopi & $0,22 \mathrm{ha}$ & 15,110 & $0,34 \mathrm{ha}$ & 20,666 & $0,89 \mathrm{ha}$ & 58,442 \\
Kulit kopi & $352 \mathrm{~kg}$ & 0,704 & $544 \mathrm{~kg}$ & 1,088 & $1.424 \mathrm{~kg}$ & 2,848 \\
Pelindung & $0,22 \mathrm{ha}$ & 2,640 & $0,34 \mathrm{ha}$ & 4,080 & $0,89 \mathrm{ha}$ & 10,680 \\
Ternak domba & $1,57 \mathrm{ST}$ & 10,953 & $1,56 \mathrm{ST}$ & 10,040 & $1,73 \mathrm{ST}$ & 10,953 \\
Kotoran ternak & $3.960 \mathrm{~kg}$ & 0,396 & $3.960 \mathrm{~kg}$ & 0,396 & $4.320 \mathrm{~kg}$ & 0,432 \\
\multicolumn{2}{l}{ Total pendapatan bersih/th } & 29,804 & & 36,270 & & 83,355 \\
\hline
\end{tabular}

Seluruh tujuan (memaksimumkan pendapatan dari usaha kebun, usaha ternak dan usahatani tanaman pangan) tercapai $100,00 \%$; dan memberikan kontribusi pendapatan yang besar kepada petani Model 1. Rerata jumlah ternak domba optimal pada seluruh 
strata Model 1 sebesar 1,59 ST. Petani Model 1 menghasilkan tambahan pendapatan bersih dari tanaman pangan (dengan pola tanam dalam setahun: padi - padi - padi), sehingga lebih mampu memelihara ternak domba dalam jumlah lebih banyak. Hasil produksi padi umumnya tidak dijual kepada pihak lain, tetapi dikonsumsi untuk keluarga.

Pendapatan bersih dan kontribusi masing-masing komponen diversifikasi usahatani optimal dalam satu tahun terakhir kelompok petani LMDH Model 2 adalah:

Seluruh tujuan (memaksimumkan pendapatan dari usaha kebun, usaha ternak dan usahatani tanaman pangan) tercapai $100 \%$; dan memberikan kontribusi pendapatan yang besar kepada petani Model 2. Rerata jumlah ternak domba optimal pada seluruh strata Model 2 sebesar 1,49 ST. Rerata jumlah ternak optimal pada Model $2=1,49$ ST lebih rendah daripada Model 1, disebabkan petani Model 1 memiliki usahatani tanaman pangan sehingga lebih mungkin memelihara ternak domba lebih banyak. Konsumsi harian pada petani Model 1 dipenuhi oleh hasil usahataninya, sedang petani Model 2 memenuhi kebutuhan konsumsi harian dari penjualan sebagian ternak domba.

\section{Perbandingan pendapatan usahatani riil dengan pendapatan optimal terbaik}

Pendapatan bersih optimal terbaik adalah pendapatan bersih tertinggi dari seluruh tujuan pada setiap model.

Tabel 5. Perbandingan pendapatan bersih/tahun usahatani riil dengan pendapatan bersih optimal terbaik

\begin{tabular}{llllll}
\hline \hline \multicolumn{5}{c}{ Model 1: Petani model 1 } \\
\hline Strata & $\begin{array}{l}\text { Pendapatan } \\
\text { bersih riil } \\
\text { (Rp/Thn) }\end{array}$ & $\begin{array}{l}\text { Pendapatan bersih } \\
\text { optimal (Rp/Thn) }\end{array}$ & $\begin{array}{l}\text { Selisih } \\
(\text { Rp/Thn })\end{array}$ & $\begin{array}{l}\text { Persentase } \\
(\%)\end{array}$ & $\begin{array}{l}\text { Status usahatani } \\
\text { riil }\end{array}$ \\
\hline 1 & $27.267 .717,95$ & $28,820,000.00$ & $1.552 .282,05$ & 5,69 & Tidak optimal \\
2 & $37.910 .000,00$ & $54.445 .000,00$ & $16.854 .000,00$ & 44,84 & Tidak optimal \\
3 & $52.695 .000,00$ & $96.417 .000,00$ & $43.722 .000,00$ & 82,97 & Tidak optimal \\
Rerata & $39.184 .572,65$ & $50.287 .342,94$ & & 45,20 & \\
\hline \multicolumn{5}{c}{ Model 2: Petani Model 2 } \\
Strata & Pendapatan & Pendapatan bersih & Selisih & Persentase & Status usahatani \\
& bersih riil & riil & \\
\hline 1 & (Rp/Thn) & Rptimal (Rp/Thn) $)$ & $(\%)$ & Tidak optimal \\
2 & $27.980 .693,78$ & $29.804 .000,00$ & $2.536 .282,05$ & 9,30 & Tidak optimal \\
3 & $29.021 .389,14$ & $36.270 .000,00$ & $7.248 .610,86$ & 24,98 & Tidak optimal \\
Rerata & $37.288 .844,16$ & $83.355 .000,00$ & $46.066 .155,84$ & 123,54 & \\
\hline
\end{tabular}

Berdasarkan rerata persentase selisih pendapatan bersih riil dengan pendapatan bersih optimal, Model 2 lebih tidak optimal dibanding Model 1 (52,61\% > 45,20\%). Kondisi optimal memberikan pengaruh positif kepada petani LMDH Model 1 dan Model 2. Pengaruh positif tujuan ekonomi adalah: (a) adanya peningkatan pendapatan petani, (b) usahatani diversifikasi tanaman - ternak domba menghasilkan pendapatan limbah perkebunan (untuk pakan ternak) dan kotoran ternak (untuk pupuk). 
Pengaruh positif tujuan lingkungan meliputi: (a) terjadinya siklus simbiose mutualistis ekosistem antara kotoran ternak dengan pakan ternak, dan kulit kopi sebagai pupuk, (b) meningkatkan kesadaran petani untuk selalu menjaga keseimbangan lingkungan terutama pada wilayah-wilayah rawan longsor seperti hutan lindung wilayah LMDH Taman Putri desa Kemiri Kecamatan Panti Kabupaten Jember. Pendapatan bersih optimal Model 1 dan Model 2 telah melampaui Kebutuhan Hidup Layak (KHL) Kabupaten Jember sebesar Rp. 16.800.000,00.

Tabel 6. Persentase kenaikan masing-masing tujuan optimal terhadap kondisi riil

\begin{tabular}{lcc}
\hline \hline Tujuan & $\begin{array}{c}\text { Model 1 } \\
(\%)\end{array}$ & $\begin{array}{c}\text { Model 2 } \\
(\%)\end{array}$ \\
\hline Ekonomi : & 97,35 & 89,90 \\
$\quad$ Rerata pertambahan pendapatan usaha kebun (Rp/Tahun) & 1,35 & 71,75 \\
$\quad$ Rerata pertambahan pendapatan usaha ternak (Rp/Tahun) & 48,70 & - \\
$\quad$ Rerata pertambahan pendapatan usahatani (Rp/Tahun) & 49,13 & 80,83 \\
Rerata tujuan ekonomi & & \\
\hline Lingkungan : & 34,17 & 38,80 \\
$\quad$ Rerata pertambahan pemanfaatan kotoran ternak domba untuk & & \\
$\quad$ pupuk (Kg/Th) & 2,92 & $5 ., 41$ \\
$\quad$ Rerata pertambahan pemanfaatan tanaman pelindung untuk & 18,55 & 22,11 \\
$\quad$ pakan ternak (Kg/Th) & & \\
Rerata tujuan lingkungan & &
\end{tabular}

Rerata pertambahan tujuan ekonomi menunjukkan angka 49,13\% dan 80,83\% mengindikasikan bahwa pada kondisi riil Model 2 lebih tidak optimal dibanding Model 1. Rerata pertambahan tujuan lingkungan sebesar $18,55 \%$ dan 22,11\% mengindikasikan bahwa pada kondisi riil Model 2 lebih tidak optimal dibanding Model 1.

Hasil optimasi Model 1 dan Model 2 untuk tujuan ekonomi dan tujuan lingkungan menunjukkan persentase kenaikan yang sama-sama positif. Hal ini mengindikasikan bahwa para petani masih memiliki peluang untuk meningkatkan pendapatan dan meningkatkan kualitas lingkungan dengan lebih optimal. Ketidak optimal petani Model 1 dan Model 2 secara riil, disebabkan: (a) petani melakukan usahatani tanpa perencanaan yang baik; (b) tanpa mempertimbangkan target capaian; (c) melakukan usahatani sesuai dengan kemampuan sumberdaya yang dimiliki; dan (d) melakukan usahatani sesuai keinginannya.

\section{Hasil analisis sensitivitas}

Hasil analisis sensitivitas Model 1. Pada Strata 1, Strata 2 dan Strata 3, koefisien fungsi tujuan (harga kopi, daun tanaman pelindung dan tanaman pangan) telah pada tingkat minimum, artinya jika harga-harga tersebut menurun, maka kondisi menjadi tidak optimal; kecuali keuntungan ternak masih bisa menurun sampai Rp 1.000.000,00/ekor. Total keuntungan dari usaha ternak sebesar Rp 10.000.000,00 merupakan target minimum. Pendapatan bersih/tahun pada kondisi optimal bisa ditingkatkan: jika harga kopi ditingkatkan menjadi Rp 23.000,00/kg, harga pakan ternak ditingkatkan menjadi Rp $240,00 / \mathrm{kg}$, keuntungan dari ternak domba ditingkatkan sampai Rp 1.200.000,00/ekor, dan harga padi ditingkatkan menjadi Rp 520.000,00/kw.

Pada Strata 1, pertambahan populasi ternak domba masih bisa ditingkatkan menjadi 0,59 ST (setara 4 ekor); sedang pada Strata 2 dan Strata 3, pertambahan populasi ternak domba telah mencapai tingkat maksimum $=0,86$ ST (setara 6 ekor). Pada Strata 1, jumlah 
pemeliharaan ternak domba masih dapat ditingkatkan menjadi 2,14 ST (setara 15 ekor), sedang pada Strata 2 dan Strata 3 dapat ditingkatkan menjadi 2,29 ST (setara 16 ekor).

Tabel 7. Analisis sensitivitas pada Model 1

\begin{tabular}{|c|c|c|c|c|}
\hline \multicolumn{5}{|c|}{ Strata 1 (Optimal terbaik) } \\
\hline Komponen & \multicolumn{2}{|c|}{ Koefisien tujuan } & Allowable Increase & Allowable Decrease \\
\hline Kopi & \multicolumn{2}{|l|}{0,021} & 0,023 & 0,021 \\
\hline Pelindung & \multicolumn{2}{|l|}{0,0002} & 0,00024 & 0,0002 \\
\hline Domba & \multicolumn{2}{|l|}{1,14} & 1,20 & 1,00 \\
\hline Padi & \multicolumn{2}{|l|}{0,500} & 0,520 & 0,500 \\
\hline Kendala & Optimal & RHS & Allowable Increase & Allowable Decrease \\
\hline $\mathrm{C} 1$ & 12,305 & 10,00 & 12,32 & 10,00 \\
\hline $\mathrm{C} 2$ & 0,29 & 0,57 & 0,57 & 0,29 \\
\hline C3 & 1,18 & 2,14 & 2,14 & 1,12 \\
\hline $\mathrm{C} 4$ & 2,160 & 1,500 & 2,200 & 1,253 \\
\hline $\mathrm{C} 5$ & 5,961 & 12,000 & 12,340 & 5,877 \\
\hline C6 & 2.880 & 2.500 & 0,295 & 0,224 \\
\hline $\mathrm{C} 7$ & 2,01 & 2,00 & 2,10 & 1,87 \\
\hline $\mathrm{C} 8$ & 0,180 & 0,200 & 0,200 & 0,175 \\
\hline C9 & 0 & 0 & 0 & 0 \\
\hline $\mathrm{C} 10$ & 0,220 & 0,200 & 0,225 & 0,190 \\
\hline \multicolumn{5}{|c|}{ Strata 2 (Optimal terbaik) } \\
\hline Kendala & Optimal & RHS & Allowable Increase & Allowable Decrease \\
\hline $\mathrm{C} 1$ & 29,082 & 25,00 & 30,32 & 25,00 \\
\hline $\mathrm{C} 2$ & 0,85 & 0,86 & 0,86 & 0,80 \\
\hline $\mathrm{C} 3$ & 1,85 & 2,86 & 2,29 & 1,65 \\
\hline $\mathrm{C} 4$ & 5,160 & 5,000 & 6,222 & 1,677 \\
\hline C5 & 10,953 & 12.500 & 15,000 & 9,555 \\
\hline C6 & 4.320 & 2.500 & 0,544 & 0,400 \\
\hline $\mathrm{C} 7$ & 2,01 & 2,00 & 2,00 & 1,87 \\
\hline $\mathrm{C} 8$ & 0,43 & 0,500 & 0,505 & 0,450 \\
\hline C9 & 0 & 0 & 0 & 0 \\
\hline $\mathrm{C} 10$ & 0,028 & 0,030 & 0,028 & 0,025 \\
\hline \multicolumn{5}{|c|}{ Strata 3 (Optimal terbaik) } \\
\hline Kendala & Optimal & RHS & Allowable Increase & Allowable Decrease \\
\hline $\mathrm{C} 1$ & 59,005 & 50,00 & 60,00 & 58,75 \\
\hline $\mathrm{C} 2$ & 0,87 & 0,87 & 0,87 & 0,80 \\
\hline $\mathrm{C} 3$ & 1,56 & 4,29 & 2,29 & 1,50 \\
\hline $\mathrm{C} 4$ & 10.440 & 10.000 & 11,250 & 9,850 \\
\hline C5 & 12,803 & 12,000 & 15,000 & 11,500 \\
\hline C6 & 4.320 & 5.000 & 0,544 & 0,400 \\
\hline C7 & 2,01 & 2,00 & 2,00 & 1,87 \\
\hline C8 & 0,87 & 1,000 & 1,005 & 0,745 \\
\hline C9 & 0 & 0 & 0 & 0 \\
\hline $\mathrm{C} 10$ & 0,048 & 0,050 & 0,051 & 0,049 \\
\hline
\end{tabular}




\section{Hasil analisis sensitivitas model 2}

Tabel 8. Analisis sensitivitas pada model 2

\begin{tabular}{|c|c|c|c|c|}
\hline \multicolumn{5}{|c|}{ Strata 1 (Optimal terbaik) } \\
\hline Komponen & \multicolumn{2}{|c|}{ Koefisien tujuan } & Allowable increase & Allowable decrease \\
\hline Kopi & \multicolumn{2}{|l|}{0,021} & 0,023 & 0,021 \\
\hline Pelindung & \multicolumn{2}{|l|}{0,0002} & 0,00024 & 0,0002 \\
\hline Domba & \multicolumn{2}{|l|}{1,140} & 1,200 & 1,000 \\
\hline Kendala & Optimal & RHS & Allowable increase & Allowable decrease \\
\hline $\mathrm{C} 1$ & 15,110 & 10,00 & 15,11 & 15,00 \\
\hline $\mathrm{C} 2$ & 0,29 & 0,57 & 0,57 & 0,29 \\
\hline $\mathrm{C} 3$ & 1,57 & 4,29 & 1,57 & 1,34 \\
\hline $\mathrm{C} 4$ & 3,960 & 1,500 & 3,960 & 2,450 \\
\hline $\mathrm{C} 5$ & 0,22 & 0,250 & 0,22 & 0,20 \\
\hline C6 & 2,01 & 2,00 & 2,01 & 2,00 \\
\hline $\mathrm{C} 7$ & 0,22 & 0,20 & 0,22 & 0,20 \\
\hline $\mathrm{C} 8$ & 0 & 0 & 0 & 0 \\
\hline \multicolumn{5}{|c|}{ Strata 2 (Optimal terbaik) } \\
\hline Kendala & Optimal & RHS & Allowable increase & Allowable decrease \\
\hline $\mathrm{C} 1$ & 20,66 & 25,00 & 22,00 & 15,00 \\
\hline $\mathrm{C} 2$ & 0,88 & 0,86 & 0,88 & 0,87 \\
\hline $\mathrm{C} 3$ & 1,56 & 4,29 & 1,57 & 1,34 \\
\hline $\mathrm{C} 4$ & 3,960 & 1,500 & 3,960 & 2,450 \\
\hline $\mathrm{C} 5$ & 0,34 & 0,250 & 0,22 & 0,20 \\
\hline C6 & 2,01 & 2,00 & 2,01 & 2,00 \\
\hline $\mathrm{C} 7$ & 0,34 & 0,500 & 0,22 & 0,20 \\
\hline $\mathrm{C} 8$ & 0 & 0 & 0 & 0 \\
\hline \multicolumn{5}{|c|}{ Strata 3 (Optimal terbaik) } \\
\hline Kendala & Optimal & RHS & Allowable increase & Allowable decrease \\
\hline $\mathrm{C} 1$ & 58,44 & 50,00 & 15,11 & 15,00 \\
\hline $\mathrm{C} 2$ & 0,88 & 0,86 & 0,88 & 0,87 \\
\hline $\mathrm{C} 3$ & 1,73 & 4,29 & 1,57 & 1,34 \\
\hline $\mathrm{C} 4$ & 4,320 & 1,500 & 3,960 & 2,450 \\
\hline $\mathrm{C} 5$ & 0,89 & 0,250 & 0,22 & 0,20 \\
\hline C6 & 2,01 & 2,00 & 2,01 & 2,00 \\
\hline $\mathrm{C} 7$ & 0,89 & 1,000 & 0,22 & 0,20 \\
\hline $\mathrm{C} 8$ & 0 & 0 & 0 & 0 \\
\hline
\end{tabular}

Strata 1, Strata 2 dan Strata 3, koefisien fungsi tujuan (harga kopi, dan daun tanaman pelindung) telah pada tingkat minimum, jika harga-harga tersebut menurun, maka kondisi menjadi tidak optimal; kecuali keuntungan ternak masih bisa diturunkan menjadi Rp 1.000.000,00/ekor.

Pendapatan bersih/tahun pada kondisi optimal bisa ditingkatkan : jika harga kopi ditingkatkan menjadi Rp 23.000,00/kg, harga pakan ternak ditingkatkan menjadi $\mathrm{Rp}$ $240,00 / \mathrm{kg}$, dan keuntungan ternak domba ditingkatkan Rp 1.200.000,00/ekor. 


\section{KESIMPULAN}

\section{Tujuan ekonomi}

a. Petani LMDH pada Model 1:

Rerata ternak domba $1,59 \mathrm{ST}$, dengan rerata kontribusi $1,35 \%$ terhadap pendapatan bersih per tahun.

b. Petani LMDH pada Model 2:

Rerata ternak domba 1,49 ST, dengan rerata kontribusi $71,75 \%$ terhadap pendapatan bersih per tahun.

\section{Tujuan lingkungan}

a. Meningkatkan pemanfaatan tanaman perkebunan kopi untuk pakan ternak domba.

Pada petani LMDH Model 1 berkontribusi sebesar 2,92\% per tahun terhadap pendapatan bersih, sedangkan pada kelompok petani LMDH Model 2 yaitu sebesar $5,41 \%$.

b. Meningkatkan pemanfaatan kotoran ternak domba untuk pupuk.

Pada kelompok petani LMDH Model 1 sebesar 34,17\% per tahun, sedangkan peningkatan pendapatan pada kelompok petani LMDH Model 2 yaitu sebesar 38,80\%.

\section{Analisis sensitivitas}

Peningkatan harga komponen diversifikasi masih bisa diupayakan sampai pada batas "allowable increase". Harga kopi (OC), tanaman pakan ternak dan padi telah pada tingkat minimum, kecuali keuntungan ternak domba masih bisa diturunkan menjadi $\mathrm{Rp}$ $1.000 .000,00 /$ ekor atau ditingkatkan menjadi Rp 1.200.000,00/ekor.

\section{DAFTAR PUSTAKA}

Dent JB, Anderson JR, 1971. Systems analysis in agriculture management. Sydney (Australia): John Wiley \& Sons Australia PTY LTD.

Devendra C. 1999. Goats, challenges for increased productivity and improved livelihoods [Internet]. [diakses $30 \quad$ Oktober 2012.]. Tersedia dari: Http://www.ilri.org/infoserv/Webpub/fulldocs/Outlk2840/Goats.htm24pages

Diwyanto K, Apriyanti. 2004. Pengembangan sistem integrasi jagung - ternak untuk meningkatkan daya saing dan pendapatan petani. Prosiding Lokakarya Nasional Sistem Integrasi Jagung - Ternak.

Effendi 1995. Sumberdaya manusia, peluang kerja dan kemiskinan. Yogyakarta (Indonesia): Tiara Wacana.

Ensminger ME. 1991. Animal science. 9th ed. Devill, Illinois (USA): The Interstate Printer and Publisher.

Ezeaku IE, Mbah BN, Baiyeri KP, Okechukwu EC. 2015. Integrated crop-livestock farming system for sustainable agricultural production in Nigeria. Afr J Agric Res. 10:42684274.

Hidayat NN. 2007. Analisis usaha ternak kambing dalam system usahatani terpadu di Kabupaten Banyumas. Anim Prod. 9:106-110. 
Rusastra IW, Saliyem HP, Supriyati, Saptana. 2004. Prospek pengembangan polatanam dan diversifikasi tanaman pangan di Indonesia. Forum Penelitian Agroekono. 22:37-53.

Shamim AM, Nusrat F, Debi MR. 2011. Integrated farming system: Prospects in Bangladesh, J Environ Sci Nat Resourc. 4:127-136.

Soedarjat S. 2000. Potensi dan prospek bahan pakan lokal dalam mengembangkan industri peternakan di Indonesia. Buletin Peternakan. Edisi Tambahan:11-15.

Sudaryanti, Endang. 2004. Faktor-faktor yang mempengaruhi produksi kopi rakyat di Kabupaten Temanggung (Studi Kasus di Kecamatan Candiroto) [Tesis]. [Semarang (Indonesia)]: Universitas Diponegoro.

Sudaryanto T, Rusastra IW. 2006. Kebijakan strategis usaha pertanian dalam rangka peningkatan produksi dan pengentasan kemiskinan. Jurnal Litbang Pertanian. 25:115122.

Sugandi D. 2007. Optimasi peran ternak domba dalam menunjang usahatani padi lahan sawah. Prosiding Lokakarya Nasional Pengembangan Jejaring Litkaji Sistem Integrasi Tanaman Ternak. Semarang. p. 17-21. 